\title{
LEGAL INSTRUMENTS FOR
}

\section{ARCHITECTURE}

Keywords

Culture

Creative industries

Services

Internationalization

Chile

\section{Architecture, cultural critical production}

\section{MARIO MARCHANT}

Profesor Asistente, Universidad de Chile

Director / Editor revista Materia Arquitectura,

Universidad San Sebastián

Santiago, Chile
Continúa en /

Continues in:

p. 152
Architecture is a material expression of culture and as such, in its many dimensions and manifestations, constitutes a social good of public interest. From that point of view, it is an interesting opportunity that the Chilean State agrees, through the National Council of Culture and the Arts, to promote and encourage its development within its cultural policies framework. This is relevant because as a country we are still in an initial stage of development and access to architecture as a public social good.

Let us not be deceived, to think that it is 'Chilean architecture' (as if indeed such a thing existed) that has achieved notoriety and international recognition in certain circuits over the last years is a misunderstanding; true and different - happily indeed - is to say that it has been the production of a select and small group of Chilean architects and scholars instead.

I welcome the fact that Chile is discussing the need to enact a Law on Promotion of Architecture, but it is important not to be confused about what is being promoted. It must be clearly distinguished that a policy supporting cultural expressions is very different from one stimulating the production and distribution of goods and services. Lack of clarity could eventually generate the exclusive benefit of private interests at the expense of state funds. Considering that the state's main concern is the broad development and welfare of society, it seems logical and coherent for architectural cultural expressions to be - for the Chilean case - within the institutional scope of a National Council or a Ministry of 
Currently in Chile, the project for a Law on Promotion of Architecture is being incubated - which hopefully should reach the legislative debate in the near future. In light of such novel legal instrument, in $A R Q$ we ask, what is this instrument for? Is architecture fostered as a creative industry or as a cultural manifestation? This is our way to participate in this discussion about a public policy that directly affects our discipline.

\section{PILAR URREJOLA}

Profesor Asociado, Escuela de Arquitectura Pontificia Universidad Católica de Chile

\section{State as architecture}

\section{sponsor}

Chile has currently three thematic Laws on Promotion within the cultural sphere: the ones related to books and reading, to audiovisuals and to music, all of them essential for the country's development, although perhaps oriented towards a specific population that not always has fluid and daily access to them.

Architecture, the territory and the cities are cultural entities common to all inhabitants - since architectural experience is inherent to the human being and therefore a constituent and fundamental factor for improving the quality of the built environment, promoting social equity, sustainability and the people's sense of life. Hence the opportunity, through the Architecture Area of the National Council of Culture and the Arts, to offer a project that precisely promotes cultural dimension beyond any creative industry.

In light of the question - what is this instrument for? it is necessary to acknowledge that the purpose of this proposal is based on three points.

First, its contribution to the development of a public interest and social good that is rooted in our territorial and landscape identity, where different human settlements develop their own materials, constructive techniques, heritage and ways of living.

Then, since these potentialities need to be valued, the project promotes formal and informal education at all levels, meant to create active awareness of the meaning and effects of urban and architectural environment over the citizenship's quality of life, the importance of participation and its role on public
Continúa en / Continues in: p. 153 
Culture. On the other hand, it is important to point out that all architectural expressions related to the provision of professional services or the 'creative industry,' are within the purview of agencies such as CORFO (the Development Corporation within the Ministry of Economy, Development and Tourism), which focuses on supporting the development of services, the creation of products and processes, access to investment finance, and the reinforcement of 'human capital,' in pursuit of the now fashionable and long-awaited triad: innovation, entrepreneurship and competitiveness.

As a cultural expression, architecture has a value in itself, as it constitutes and builds a heterogeneous social and historical heritage of ideas, spaces and behaviors, generating a material body of knowledge that is constantly evolving. A state policy for the promotion of architecture should focus on enhancing, developing and strengthening the discipline's forms of knowledge and modes of expression; since its practices - in its different ways of thinking and doing - shape social, political and cultural structures. A law boosting architecture should ensure the space and critical freedom of action for the formation, production, conservation and circulation of architecture in its own means and media, not only in the traditional building field.

Undoubtedly, and especially considering modern discourse, architecture is not so much reduced to buildings but rather constituted within a complex cultural, social and political relationship (in its broadest sense) between body and building. There on, society's much needed illusion of stability - proper of traditional architectural forms, practices and institutions based on the logic of service - is nowadays in conflict with the discipline, that is, with that sphere of architectural knowledge that has the potential to be critically analyzed. When this happens, the instability of architecture is indisputably evident, something proper to a cultural expression. Questioning, crisis and change with regard the production of space are at its core, becoming a valuable place of experimentation, creation and research. The Law on Promotion of Architecture should then consider the latter, becoming the framework allowing us - as a society - to understand and to value architecture as a design discipline; as a space to rethink the dimensions of the public sphere through its critical production. ARQ

Mario Marchant L.

$<$ mmarchant@uchilefau.cl> 
opinion, authorities and privates, enabling well-informed and participatory processes of decision making.

Thirdly, it implies encouraging knowledge and good practices in order to promote quality among architectural and urban projects, with the State providing sustained and permanent support to enhance the cultural dimension while promoting and disseminating strategic initiatives to improve the built environment as a formative, creative and identitarian expression.

Chile has received considerable international attention in recognition of its architectural production in recent years. This has meant an escalation in the country's image that, although having a certain impact at national level, has not yet been sufficiently considered in terms of the contribution that these professionals can make at public and private levels.

In view of this, the project for a Law on Promotion is an instrument for the expansion of knowledge production, innovation, creativity and talent. This will allow to achieve substantial advances of architecture's cultural dimension and to enhance its contribution to collective life, together with an evolution of our cities and territories promoted by public funding tending to value a social good of national interest - different from that of a professional practice, whose financing is usually limited to private or public commissions restricted to a specific project.

With our country in a situation of exceptional development - one possibly unique in its history - it should be considered that there are many States with which we have international treaties and agreements that have been developing, for years, cultural policies that include the promotion of architecture for both forging identity and contributing to social and economic development.

The State's possibility of opening up new fields and opportunities to support, promote and disseminate the value of urban and architectural works, infrastructure, public spaces and buildings through concrete and continuous actions will undoubtedly be a contribution to culture, diversity and social cohesion. ARQ

\section{Pilar Urrejola D.}

<durrejol@uc.cl>

Architect, Universidad de Chile, 1979. Doctoral candidate, Doctorado en Arquitectura y Estudios Urbanos, Pontificia Universidad Católica de Chile. She has been President of the XI Chilean Biennial of Architecture in 1997 and Events Coordinator at the Facultad de Arquitectura y Bellas Artes uc until 2000. She was President of the Colegio de Arquitectos de Chile (2015-2017). She is currently Associate Professor at the School of Architecture uc. 